INFORMAATIOTUTKIMUKSEN PÄIVÄT 2020

\title{
Avoin tiede tiedeneuvonnan edistämisessä - tietopalveluiden rooli
}

\author{
Katja Hilska-Keinänen \\ Suomen ympäristökeskus, Information Services \\ katja.hilska-keinanen@ymparisto.fi \\ https://orcid.org/0000-0003-2727-8048
}

Asiasanat: tietopalvelu, tiedelehdet, tieteellinen julkaiseminen, open access, rinnakkaisjulkaiseminen

\section{Kompleksiset ongelmat vaativat monitahoista tieto- tukea}

Monimutkainen toimintaympäristö asettaa päätöksentekijöille haasteita tietopohjaisen politiikan toteuttamisessa. Äkilliset kriisit ja laajavaikutteiset, monitahoiset ilmiöt vaativat tulkintansa tueksi ja tarkoituksenmukaisten toimenpiteiden aikaansaamiseksi tutkittua tietoa. Tieteellisen tutkimuksen tuottamat, luotettavat tutkimustulokset ja niiden merkitys olisi tuotava Artikkeli on lisensoitu Creative Commons Nimeä-EiKaupallinen-JaaSamoin 4.o Kansainvälinen -lisenssillä Pysyvä osoite: https://doi.org/10.23978/inf.99070 
yhteiskunnalliseen ongelmanratkaisuun poliittisen päätöksenteon vaatimalla nopeudella ja käytettävyydellä sekä tarjoamalla mahdollisuuden tulosten luotettavuuden ja toimenpiteiden vaikuttavuuden arviointiin. (Hellström et al., 2019; Kuosmanen \& Sivonen, 2020; Saarela, 2020.)

Suomessa tiedeneuvonnan prosesseja ovat kehittäneet $\mathrm{mm}$. Sitran Tieto päätöksenteossa -hanke (Hellström et al., 2020) ja yhä käynnissä oleva, kolmivuotinen Tiedeakatemioiden tiedeneuvonnan hanke Sofi (Kuosmanen \& Sivonen, 2020). Tiedeneuvonnan keinoja ovat mm. tiedesparraus, tutkijapaneelit, tieteellisten seurojen, komiteoiden ja neuvottelukuntien toiminta sekä Eduskunnan tutkijakummitoiminta (Kuosmanen \& Sivonen, 2020). Valtioneuvoston kanslia on aloittanut vastikään laajaa tutkijaverkostoa hyödyntäen COVID 19 -aiheisten tutkimussynteesien kokoamisen ja nopeatahtisen julkaisemisen.

Eurooppalaisessa tiedeneuvonnan keskustelussa on tuotu esiin myös tutkimusdatan avoimuuden merkitys tutkimustulosten luotettavuuden arvioimiselle. On kuitenkin huomioitava, että pelkästään tiedon tarjonta ei ratkaise sen käyttöä päätöksenteossa, vaan tiedon käyttöön vaikuttavat myös mm. päätöksentekijöiden arvot ja asenteet sekä vallitseva päätöksenteon konteksti (Mair et al., 2019).

On myös nähtävissä, että pätöksenteon prosesseja ja niissä tapahtuvaa tieteen tekijöiden ja politiikkaa valmistelevien virkamiesten vuorovaikutusta kuvaa erillisten tilanteiden ja tapahtumien jatkumo, joissa tyypillistä on tietynlainen hierarkkisuus ja käytettävissä olevan ajan rajallisuus - toisaalta myös matalahierarkkisuus kansainväliseen kenttään verrattuna ja tutkijoiden ja virkamiesten henkilökohtaiset suhteet. Esimerkiksi ympäristöhallinnossa tutkijoiden ja valmistelevien virkamiesten välinen suhde on alkanut kehittyä vuorovaikutteisempaan suuntaan vasta viime vuosina ja vuorovaikutuksen mekanismien kehittäminen vaatii edelleen työtä ja reflektointia (Saarela, 2020).

\section{Tietopalveluiden mahdollisuudet tiedonkäytön tukemisessa}

Tiedontarpeiden kompleksisuuden lisääntymisen myötä tarvitaan uudenlaista lähestymistapaa tiedonkäytön tukemiseen: tietoa välittävästä tietotuesta tulisi siirtyä dialogia aktivoivaan ja osallistavaan tietotukeen (Hellström et al., 2019). Tutkimuksen tukipalveluiden kentällä, esimerkiksi tutkimuslaitosten tietopalveluissa, olisikin nostettava pohdintaan, miten omalla toiminnalla voidaan tukea tiedeneuvonnan prosesseja. 
Vaikka tiedeneuvonnan välineet, kuten tiedepaneelit ja tiedesparraukset, ovat tutkijoiden ja politiikkaa valmistelevien tahojen välistä vuorovaikutusta, olisi myös tietopalvelukentällä tärkeää herätä niihin vaatimuksiin ja mahdollisuuksiin, joita tiedeneuvonnan tukeminen tuo. Yksi näistä mahdollisuuksista on tutkimustulosten ja -julkaisujen löydettävyyden edistäminen ja niiden avoimen saatavuuden varmistaminen. Keskusteltaessa pääsystä tietoon, kääntyy huomio yleensä tutkimuslaitosten ja yliopistojen kirjastoihin.

Avoimen tieteen tukeminen onkin keskeinen toimintakenttä tutkimusorganisaatioiden tietopalveluille ja kirjastoille. Tietopalveluiden asiantuntemuksella ja raportointivälineillä on mahdollista sekä tukea avointa julkaisemista ja avointa tiedettä että tarkastella avoimen toimintakulttuurin näkyvyyttä ja vaikuttavuutta. Varmistamalla tieteellisten artikkeleiden yhä laajemman avoimen julkaisemisen, on tutkittu tieto helposti päätöksentekijöiden ja kansalaisten saatavilla. Myös tieteellisten tulosten arviointi ja tutkimuksen luotettavuuden varmistaminen tehdään laajalle lukijakunnalle mahdolliseksi tukemalla avointa tiedettä.

Tiedeneuvonnan haasteita voidaan siis tukea tutkimusorganisaatioiden tietopalveluiden taholta panostamalla tutkimuksen tuen viitekehyksessä erityisesti avoimen tieteen tukemiseen. Tutkijoiden ja tutkimushankkeiden näkyvyyden tukeminen on tietopalveluiden perinteinen toimintakenttä ja tämä luo pohjan myös avointen tutkimustulosten saavutettavuudelle. Tukemalla avointa toimintakulttuuria, tuetaan myös keskustelumahdollisuuksia tutkijoiden ja päätöksentekijöiden välillä. Mahdollistamalla avoin pääsy tietoon ja nostamalla tarkasteluun myös vuorovaikutuksen tukeminen, vahvistetaan tutkimushankkeiden vaikuttavuutta ja tiedon hyödyntämistä yhteiskunnallisessa päätöksenteossa. Nämä uudet toiminnot vahvistavat myös tietopalvelukentän toimintaedellytyksiä digitalisoituneessa ja verkostoituneessa maailmassa.

Esitelmässä tarkastellaan, miten tiedeneuvonnan haasteita voitaisiin tukea yliopistokirjastojen ja tutkimuslaitosten tietopalveluiden taholta panostamalla tutkimuksen tuen osalta avoimen tieteen tukemiseen, tutkijoiden löydettävyyteen ja tutkimustiedon saavutettavuuteen. Tukemalla avointa julkaisemista, datan avoimuutta ja avointa toimintakulttuuria, tuetaan tutkimustiedon löydettävyyttä, saatavuutta, uudelleenkäyttöä ja luotettavuuden varmistamista. Mahdollistamalla avoin pääsy tietoon vahvistetaan tutkimushankkeiden vaikuttavuutta ja tiedon hyödyntämistä yhteiskunnallisessa päätöksenteossa. Esitelmän tavoitteena on osoittaa käytännönläheisiä mahdollisuuksia tietoasiantuntijoiden osallistumiselle tiedeneuvonnan prosesseihin. 


\section{Lähteet}

Gluckman, P., \& Wilsdon, J. (2016). From paradox to principles: where next for scientific advice to governments? Palgrave Communications, 2: 16077. https://doi.org/10.1057/ palcomms. 2016.77

Hallituksen toimintasuunnitelma. Osallistava ja osaava Suomi - sosiaalisesti, taloudellisesti ja ekologisesti kestävä yhteiskunta. Valtioneuvoston julkaisuja, 2019:27. http://urn.fi/URN: ISBN: 978-952-287-789-5 [21.9.2020]

Hellström, E., Ikäheimo, H-P., Hakapää, J., Lehtomäki, J., \& Saari, M. (2019). Tiedonkäytön tulevaisuus yhteiskunnallisessa päätöksenteossa. Sitra. https://www.sitra.fi/julkaisut/ tiedonkayton-tulevaisuus-yhteiskunnallisessa-paatoksenteossa/ [21.9.2020]

Kuosmanen J., \& Sivonen M. H. (2020). Tiedeneuvonta poliittisen päätöksenteon tukena. Tieteessä tapahtuu, 38(1). https://journal.fi/tt/article/view/89791 [21.9.2020]

Mair, D., Smillie, L., La Placa, G., Schwendinger, F., Raykovska, M., Pasztor, Z., \& van Bavel, R. (2019). Understanding our political nature: How to put knowledge and reason at the heart of political decision-making. European Commission, Joint Research Centre EUR, 29783. https://ec.europa.eu/jrc/en/publication/eur-scientific-and-technical-researchreports/understanding-our-political-nature-how-put-knowledge-and-reason-heartpolitical-decision [21.9.2020]

Saarela, S-R (2020). In between two worlds? Science-policy interaction in Finnish environmental governance. Doctoral dissertation. University of Helsinki, Faculty of Biological and Environmental Sciences. Doctoral Programme in Interdisciplinary Environmental Sciences. Helsingin yliopisto. http://urn.fi/URN: ISBN: 978-951-51-5933-5 